\title{
Palaeopathology: \\ The Study of Disease in the Past
}

\author{
Pedro L. Fernández \\ Department of Pathology, Hospital Clínic and Institut d'Investigacions August Pi i Sunyer, University of Barcelona, \\ Barcelona, Spain
}

\section{Key Words}

Anthropology • Antiquity · Archaeology • Mummy •

Palaeopathology

\begin{abstract}
Palaeopathology studies ancient human or animal remains from a pathological point of view, for which techniques and tools such as inspection and light and electron microscopy after adequate rehydration, immunohistochemistry and molecular biology are used. Despite the degradation of tissues, partial preservation of their structure and content after a natural or artificial mummification process often allows the extraction of valuable biological data, which sometimes provides interesting historical information.
\end{abstract}

Copyright $\odot 2012$ S. Karger AG, Basel

\section{Introduction}

Palaeopathology is the medical discipline dedicated to the study of disease occurring in the past which, in many cases, still afflicts the present. Interest in palaeopathology was already present in classic scholars like Virchow, who studied a Neanderthal skull, and other scientists of the XIX century such as Pettigrew, who had the interest and opportunity to study mummified subjects (mostly provided after the invasion of Egypt by Napoleon) [1-3].

\section{KARGER}

Fax +4161306 1234

E-Mail karger@karger.ch

www.karger.com
(C) 2012 S. Karger AG, Basel

$1015-2008 / 12 / 0795-0221 \$ 38.00 / 0$

Accessible online at:

www.karger.com/pat
The science of palaeopathology has classically been related to the study of pathological bones, since these are the most common remains found in archaeological sites due to their durability. Thus, many so-called paleopathologists have emerged from the field of physical anthropology, although a lot of them did not always have sufficient medical background to support reliable medical conclusions. This became even more evident and important when studies involved subjects far better preserved than mere osseous elements. Indeed, the study of partially or completely mummified individuals imposed the need for precise histological techniques capable of extracting valuable new information from soft tissues. Paramount examples of the latter are the numerous and variegated studies performed in such incredibly well preserved subjects as the Tyrol Iceman [4], some Egyptian mummies [5] and even a 44,000-year-old mammoth [6].

Beside the obvious good preservation of bony samples, soft tissues are sometimes relatively well preserved by a natural or artificial desiccation process called mummification, which can occur in dry hot or cold environments $[1,2,7,8]$. More rarely, soft tissues can be preserved in a humid environment when the right conditions of anaerobiosis or chemical composition are present [9]. Some years ago, a replication of traditional Egyptian mummification was performed [10] providing evidence of the usefulness of this ancient technique as well as the little degradation of ancient mummified tissue occurring over the passage of time.

Dr. Pedro L. Fernández, MD, $\mathrm{PhD}$

Department of Pathology, Hospital Clínic-IDIBAPS

University of Barcelona, Villarroel 170

ES-08036 Barcelona (Spain)

Tel. +34 93227 5450, E-Mail plfernan@clinic.ub.es 


\section{Techniques}

Palaeopathological methods have evolved along with those related to medicine, thereby taking advantage of simple but very valuable macroscopic inspection on the one hand and sophisticated imaging and molecular techniques on the other. Thus, the approach to palaeopathological samples depends on the nature of the sample itself (e.g. bone, soft tissue or hair), its size (from minimal fragments to full bodies), the degree of preservation and, very importantly, the manipulation allowed (from intact sample ready for display to absolute access and freedom to undertake any kind of valuable destructive analysis including a full autopsy study). Therefore, both non-invasive (imaging) and invasive procedures can be applied to subjects and samples in palaeopathology. Among the former, X-ray and computerized tomography yield highquality information, being, in many instances, the only techniques allowed since they do not harm the sample or individual. Nevertheless, a detailed description of the advantages and possibilities of these techniques, including $3 \mathrm{D}$ reconstruction, would require a full review and previous reports provide exhaustive information $[4,9,11]$.

\section{Macroscopy}

Inspection of bones has traditionally been a key tool in the diagnosis of pathology in bony samples $[1,11,12]$ but its importance is also evident when dealing with mummified individuals. Indeed, the discovery of postmortem alterations of the body caused by human intervention related to funerary practices, such as evisceration in Egyptian mummies, cranial deformations [13] or excarnation and disarticulation in the Chinchorro culture [14, 15], may be readily observed by the naked eye. In other instances, interesting cultural practices on living individuals, such as tattoos, can be easily documented [16]. Finally, the differential diagnosis between actual external pathologies (fractures, amputation and wounds) and taphonomic or artificial destructive interventions, including profanation, can frequently be documented by simple inspection. It is worthy to point out that often the external appearance and even the touch of mummified internal organs closely resemble hard old leather [pers. observation]. Most interestingly, stomach and bowel content, including feces, are the samples most frequently sought to gain information on diet and parasitic pathologies [17].

\section{Light Microscopy}

The application of palaeopathological studies to mummified subjects provided pathologists with the opportu- nity to introduce microscopic studies into ancient samples and to be introduced into the fascinating discovery of how and why the passage of time affects cells and tissues. One of the pioneers of this discipline was Ruffer [18], who described the first method of rehydration of soft tissues at the beginning of the XX century and several pathologies, including schistosomiasis, tuberculosis and atherosclerosis among others [2, 18]. Sandison [19], Cockburn et al. [20], Zimmerman and Kelley [21], Aufderheide and RodriguezMartín [1] and Aufderheide [2] were not only pioneers in this field but also developed new technical approaches and contributed lengthy written documents on palaeopathology [1, 2, 19-21] while Allison et al. [17, 22, 23] made extensive studies on South-American mummies and founded the Palaeopathology Club (http://www.pathology.vcu. edu/paleo/index.html), a forum and valuable source of information for pathologists interested in this discipline.

Mummified tissues require a rehydration process prior to microscopic study, with the most popular solutions being those of Ruffer [18] and Sandison [24], both of which are based on an alcoholic solution with sodium carbonate, although several other solutions have also been proposed [25]. The degree of degradation and the time required for rehydration vary between individuals and even between tissues within a given individual, with more recent samples not always being better preserved or needing less rehydration. After immersion of tissue fragments in rehydration solution, they must be checked every 10-20 min for adequate consistency to avoid irrecoverable disaggregation. Once the right consistency is obtained, usually indicated by personal experience, the tissue samples are processed as regular surgical pathology specimens with formalin, alcohols, xylene and paraffin to obtain a paraffin block which will provide tissue sections and may thereafter be subjected to histochemical or immunohistochemical staining. Interestingly, one has to be aware of the unusual results of routine stains like hematoxylin and eosin, which frequently show a tendency to produce unexpected hues. As mentioned previously, preservation varies with tissue type, with the pancreas, liver, brain and generally organs which are very enzymatic and with little stroma usually being almost unrecognizable. On the other hand, the skin, spleen or kidney are usually readily identified and some pathologies can frequently be diagnosed [26] (fig. 1, 2). One of the first things to strike the novel paleopathologist when performing a light-microscopic study of mummified tissues is the complete absence of nuclei. Indeed, nuclear degradation occurs early in the decay of tissues but dehydration seems, at some point, to stop the destructuration of 
Fig. 1. Modern (a) and pre-Columbian mummified skin showing a pilosebaceous complex (b HE; c trichrome stain). Modern (d) and pre-Columbian mummified gastric mucosa. Note absence of nuclei (e HE; f trichrome stain; reprinted with permission from Fernández and Esteban [26]).
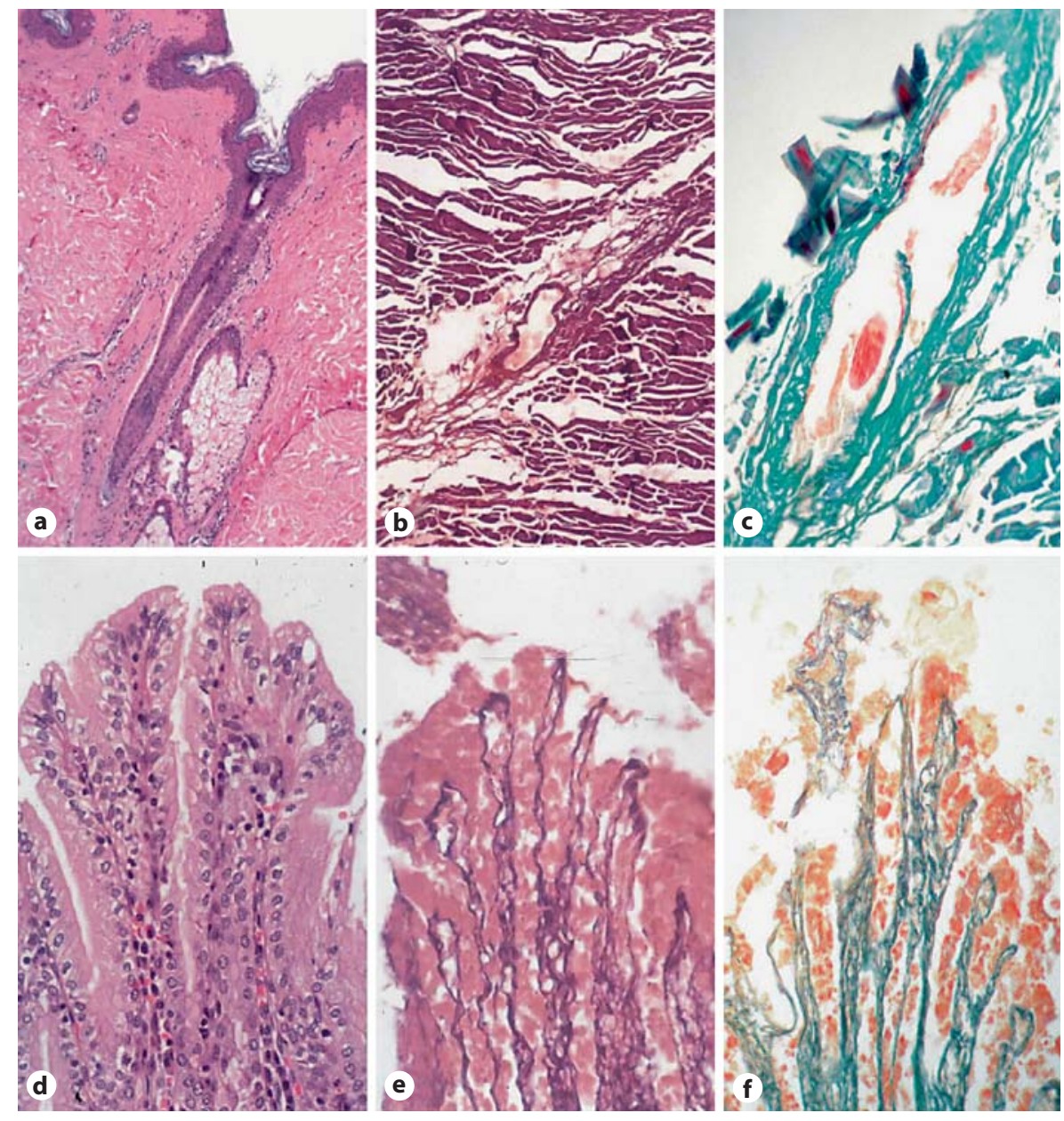

organs, mainly when a dense fibrillary extracellular matrix is present. Contrarily, cytoplasms are frequently recognizable, mostly in epithelial tissues (fig. 1, 2). Interestingly, the application of these rehydration techniques to incorrectly processed modern tissue samples (i.e. accidental desiccation) can be considered, since it may prove useful to recover morphology to a great extent, thus making microscopic diagnosis possible [pers. observation].

\section{Electron Microscopy}

Likewise, transmission electron microscopy is possible after processing of the tissue with or without prior rehydration, and different studies have shown good preservation of the tissue and cellular structures at the electron-microscopic level [27-30]. Indeed, we have obtained good results in 3,000-year-old brain tissue which showed recognizable myelin sheaths (fig. 3 ).

Similarly, 3D high-resolution images can be obtained through scanning electron microscopy, which provides valuable information of the surfaces and inner structure of tissues [31].

\section{Immunohistochemistry}

As mentioned earlier, immunohistochemical and immunofluorescence analyses can be performed in rehydrated tissues. Although they frequently provide negative results, some antigens in some tissues of some mummified subjects show astonishing antigenic preservation of immunogens, e.g. collagens [32], neuropeptides [33] and even biological agents [23]. Not surprisingly, successful immunostaining seems to largely depend on tissue preservation and the right combination of rehydration and fixation solutions $[34,35]$, and careful attention to artifacts and expected results in internal controls of the samples are mandatory. In our experience, actin is a durable antigen in some mummified samples and we have achieved good results in a mummified pre-Columbian kidney (fig. 4). 

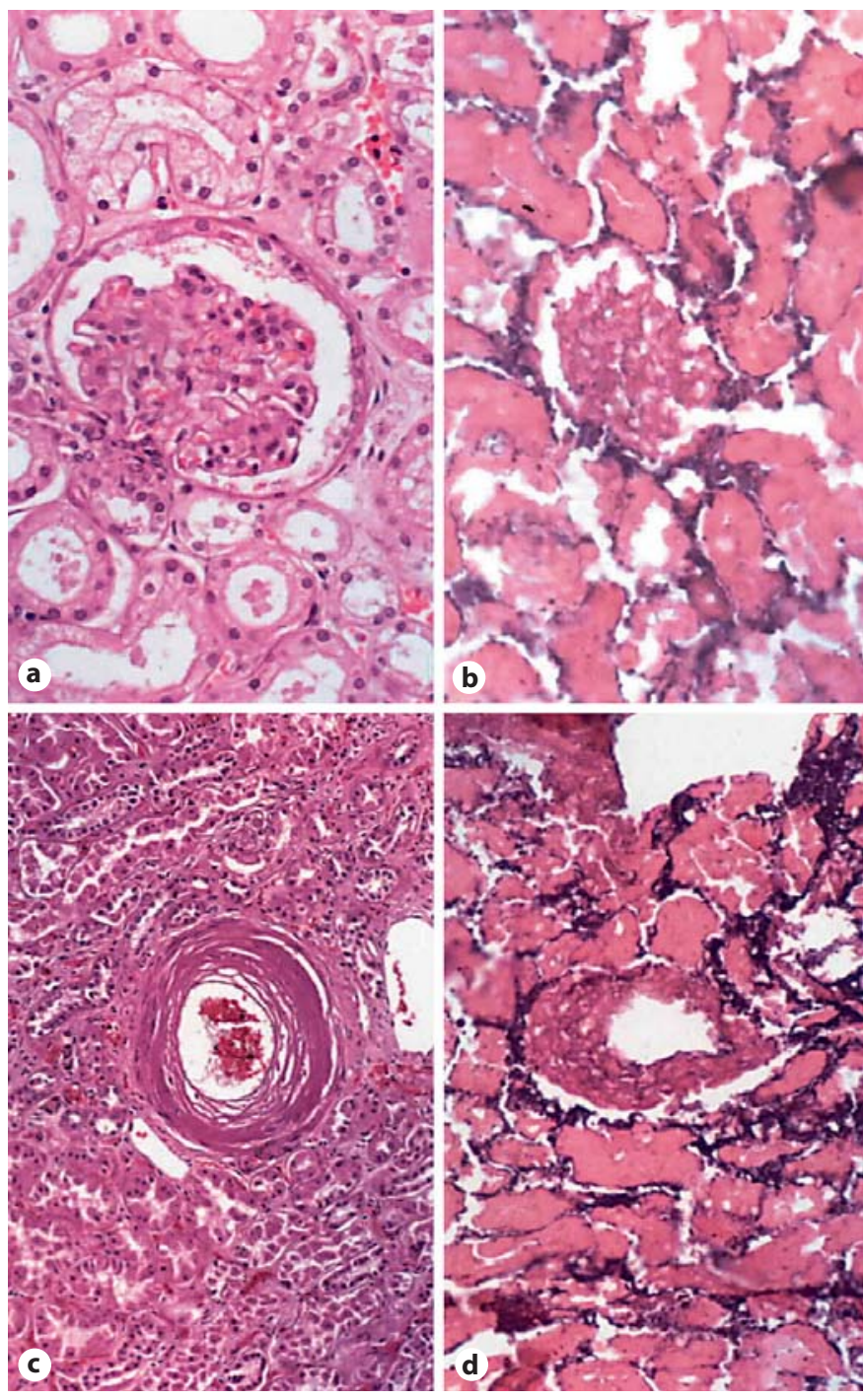

Fig. 2. Modern (a) and pre-Columbian mummified kidney showing a glomerulus and tubules (b). Modern (c) and pre-Columbian renal arteriole with concentrical thickening consistent with hypertensive changes (d). HE (reprinted with permission from Fernández and Esteban [26]).

\section{Molecular Studies}

Both bony and soft tissue samples can be subjected to molecular studies as demonstrated by the success of this type of analysis in such incredibly old and poorly preserved samples as those of mammoths or even, not yet totally confirmed, dinosaurs $[36,37]$. The appropriate names for this discipline could be molecular palaeopathology or molecular palaeontology [38]. In addition, good results can be expected with a great variety of possible studies of ancient subjects including genetic and en-

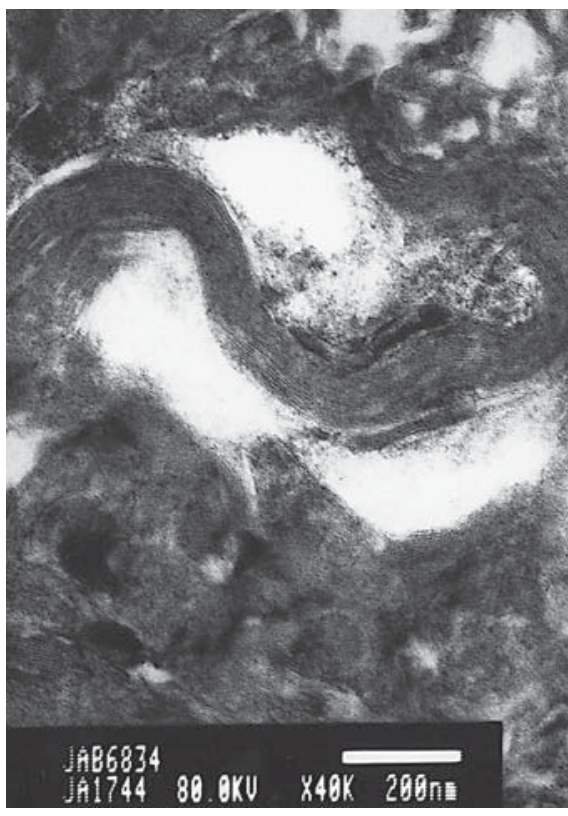

Fig. 3. Electron-microscopic image of 3,000-year-old brain tissue showing periodic laminar structures consistent with myelin sheaths (center). $\times 40,000$.

zymatic studies. Among the former, DNA recovery, both genomic and mitochondrial, is often possible (in spite of nuclear and organelle disappearance), and PCR-based techniques frequently provide enough template to perform different genetic tests [39-41]. On the other hand, there are few reports on the preservation of ancient RNA, which is assumedly more degraded due to the rapid action of RNAses after cell death, although several authors have reported successful extraction and analysis of this type of molecule from mummified tissues [42]. Not surprisingly, cross-contamination due to sloppy management of samples is a frequent nightmare in molecular studies of ancient tissue, and extreme caution is mandatory during their recovery and along all the phases of their processing.

\section{Diseases in Ancient Subjects}

Both neoplastic and non-neoplastic conditions have been reported in ancient bodies. Among the former, and apart from osseous evidence of malignancies and benign tumors [11], different types of neoplasms such as histiocytomas, adenocarcinomas and metastases have been described in mummified tissues [3,43-46]. It is interesting to point out that cancers are rarely encountered in pal- 


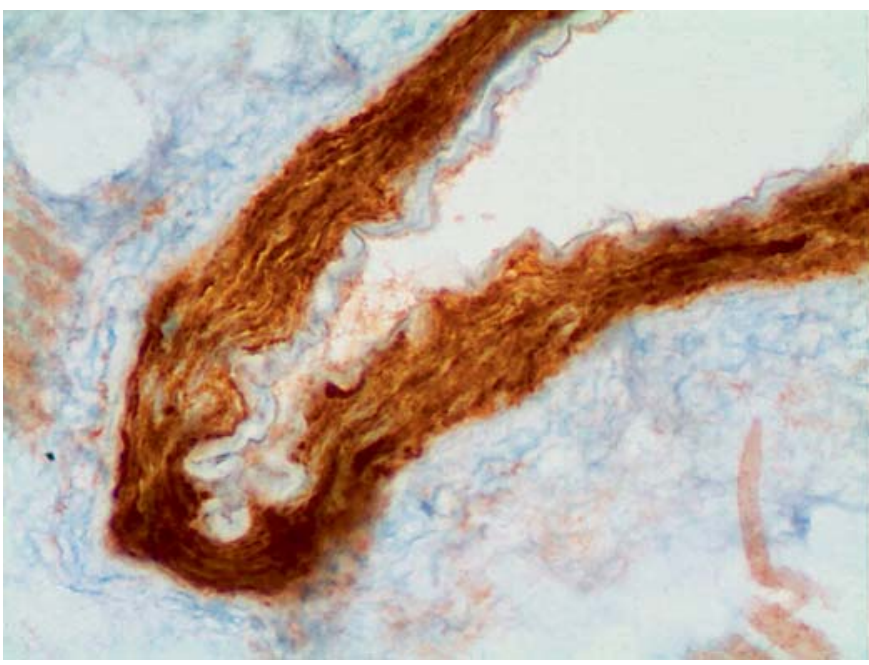

Fig. 4. Immunohistochemical staining for actin showing positivity on the wall of a renal arteriole from a pre-Columbian mummy (diaminobenzidine/hematoxylin, $\times 400$ ).

aeopathological studies, which could have several, albeit not definitive, explanations, including the absence of chemical environmental contamination, shorter life expectancy or simply the disappearance of tissue evidence given the frequent origin in and involvement of soft tissues $[3,47,48]$. Infectious diseases such as tuberculosis and treponematosis in ancient Egypt and the pre-Columbian New World [49-51], Helicobacter pylori [52], malaria [53], smallpox [54] and different types of parasitic diseases $[3,55,56]$ are abundant in the literature. Other conditions such as bone degenerative processes in SouthAmerican mummies, which indicate the high prevalence of vertebral degenerative changes and the scarcity of metastases to bone in this area [57], as well as some endocrine pathologies, including goiter [58], and tissue deposits as in pneumoconiosis [59] have also been reported.

\section{Seminal Studies in Palaeopathology}

It would be an arduous task to review all the important palaeopathological studies since the first in the XIX century, therefore, a review of previous works addressing the history of palaeopathology is suggested [1-3]. Among the extensive, albeit limited compared to other medical disciplines, literature on palaeopathology, several reports, excluding books, merit special mention because of their historical interest and repercussion in the media, mainly during the last 20 years.

The Study of Disease in the Past
The extensive breakthrough studies of Elliot Smith, Ruffer and Lucas in a large number of Egyptian mummies were the starting point of the scientific development of the field of paleopathology (see Aufderheide and Lynnerup for a review) [1-3]. Technical developments, including fixation methods by Ruffer and Sandison, pioneer molecular approaches by Pääbo [60] and, very importantly, the multidisciplinary approach to the study of the Tyrolean Iceman $[4,30,59]$ and similarly well preserved subjects such as the Arctic and bog mummies [61, 62] have fuelled the extraction of massive amount of relevant information from palaeopathological projects.

\section{Usefulness and Successes of Palaeopathology}

Historical knowledge is, obviously, the most important contribution of palaeopathology, mainly when it helps to clarify medical events which could have influenced history. Nonetheless, great expectations are sometimes deposited on the possibility of achieving a final diagnosis with histopathological techniques performed on mummified tissues, to only be followed by great disappointment when microscopy is often unable to even identify the tissue type, much less a diagnosis of the cause of death or any pathological condition. This is to be expected when current autopsy studies on perfectly preserved subjects are often not able to reach a definitive diagnosis. Therefore, paleopathologists must bear and transmit a humble approach to mummified individuals and an advice of the improbable discovery of an undisputable or even likely cause of death.

Nevertheless, surprisingly precise results about lifestyle and cause of death can sometimes emerge from this type of studies. A paradigm of the latter is the case of Ferrante I of Aragon, King of Naples during the XV century who, according to the microscopic and molecular results provided by Marchetti et al. [63], most likely died of colorectal cancer, according to our knowledge, the first bona fide molecular demonstration of a malignant neoplasm in a historical subject. Similarly, the reported death of Francesco I of Medici by malaria and the severe gout of Emperor Charles V of Augsburg, most likely influenced some historical events during the XVI century [64, 65]. Very recently, the family lineage and the pathologies affecting Tutankhamen and his possible cause of death have been widely covered by the media and have led to a renewed interest in palaeopathology [66]. In addition to the above analysis of historical subjects, other possible fruitful applications of palaeopathology involve the use 
of mummified samples for analyzing social habits, such as tattooing [16], medical skills [67, 68] and diet $[41,69]$, from which a great deal of valuable knowledge can be extracted. We thus dare to foresee that the great interest in antiquity in general, and mummified subjects in particular, coupled with technical developments will soon promote the development of authentic banks of palaeopathological tissues ('palaeobanks'?) as a source of valuable samples for multidisciplinary knowledge.

\section{Concluding Remarks}

Palaeopathology is not only a hobby or an original application of pathology. Instead, it is a scientific crossroad nurtured by history, archaeology, anthropology and medicine, and it is in a unique position to provide all of these fields with an integrated vision of diseases and lifestyle habits, which can help to understand how men, and sometimes animals, lived and died in ancient times.

\section{Acknowledgments}

This work is dedicated to my mentor in Palaeopathology, Prof. Enrique Gerszten, and his colleague Marvin Allison (Medical College of Virgina) for their generous teaching and for sharing their extensive knowledge and invaluable samples during the last 20 years. I owe special gratitude to Dr. Jordi Esteban and Dr. Bombi for their help, patience and, most importantly, friendship during our palaeopathological ordeals. Finally, Montserrat Tortosa and Eva Fernandez have been the best 'palaeopathological' assistants any pathologist could have.

\section{References}

1 Aufderheide AC, Rodriguez-Martín C: History of paleopathology; in Aufderheide AC, Rodriguez-Martín C (eds): The Cambridge Encyclopedia of Human Paleopathology. Cambridge, Cambridge University Press, 1998, pp 1-7.

2 Aufderheide AC: History of mummy studies; in Aufderheide AC (ed): The Scientific Study of Mummies. Cambridge, Cambridge University Press, 2003, pp 1-17.

3 Lynnerup N: Mummies. Am J Phys Anthropol 2007;suppl 45:162-190.

-4 Seidler H, Bernhard W, Teschler-Nicola M, Platzer W, zur Nedden D, Henn R, Oberhauser A, Sjøvold T: Some anthropological aspects of the prehistoric Tyrolean ice man. Science 1992;258:455-457.

-5 Walker R, Parsche F, Bierbrier M, McKerrow JH: Tissue identification and histologic study of six lung specimens from Egyptian mummies. Am J Phys Anthropol 1987;72: 43-48.

6 Reyman TA, Goodman M: The histology of ancient mammoth tissue. Paleopathol Newsl 1981;33:13-15.

7 Zimmerman MR, Tedford RH: Histologic structures preserved for 21,300 years. Science 1976;194:183-184.

8 Zimmerman MR, Trinkaus E, LeMay M, Aufderheide AC, Reyman TA, Marrocco GR, Ortel RW, Benitez JT, Laughlin WS, Horne PD, Schultes RE, Coughlin EA: The paleopathology of an Aleutian mummy. Arch Pathol Lab Med 1981;105:638-641.

-9 Lynnerup N: Medical imaging of mummies and bog bodies - a mini-review. Gerontology 2010;56:441-448.
10 Zimmerman MR, Brier B, Wade RS: Brief communication: twentieth-century replication of an Egyptian mummy: implications for paleopathology. Am J Phys Anthropol 1998; 107:417-420.

11 Campillo D: Introducción a la paleopatología. Barcelona, Bellaterra, 2001.

12 Baixarias J, Herrerin J: The Handbook of Paleopathology. Barcelona, Generalitat de Catalunya, Departament de Cultura i Mitjans de Comunicació, 2008.

13 Gerszten PC, Gerszten E: Intentional cranial deformation: a disappearing form of selfmutilation. Neurosurgery 1995;37:374-381.

14 Aufderheide AC, Muñoz I, Arriaza B: Seven Chinchorro mummies and the prehistory of northern Chile. Am J Phys Anthropol 1993; 91:189-201.

15 Aufderheide AC: Mechanisms of mummification; in Aufderheide AC (ed): The Scientific Study of Mummies. Cambridge, Cambridge University Press, 2003, pp 41-71.

16 Dorfer L, Moser M, Bahr F, Spindler K, Egarter-Vigl E, Giullén S, Dohr G, Kenner T: A medical report from the stone age? Lancet 1999;354:1023-1025.

17 Allison MJ, Bergman T, Gerszten E: Further studies on fecal parasites in antiquity. Am J Clin Pathol 1999;112:605-609.

18 Ruffer MA: Pathological notes on the royal mummies of the Cairo museum; in Moodie RL (ed): Studies in the Paleopathology of Egypt. Chicago, University of Chicago Press, 1921, pp 166-178.

19 Sandison AT: The study of mummified and dried human tissues; in Brothwell D, Higgs E (eds): Sciencie in Archeology. London, Thames \& Hudson, 1963, pp 413-425.
20 Cockburn A, Barraco RA, Reyman TA, Peck WH: Autopsy of an Egyptian mummy. Science 1975; 187:1155-1160.

21 Zimmerman MR, Kelley MA: Atlas of Human Paleopathology. New York, Praeger, 1982.

22 Allison MJ, Gerszten E, Shadomy HJ, Munizaga J, Gonzalez M: Paracoccidioidomycosis in a Northern Chilean mummy. Bull NY Acad Med 1979;55:670-683.

23 Allison MJ, Bergman T, Gerszten E: Further studies on fecal parasites in antiquity. Am J Clin Pathol 1999;112:605-609.

24 Sandison AT: The histological examination of mummified material. Stain Technol 1955,30:277-283.

25 Aufderheide AC: Mummy study methology; in Aufderheide AC (ed): The Scientific Study of Mummies. Cambridge, Cambridge University Press, 2003, pp 322-394.

26 Fernández PL, Esteban J: Estudio anatomopatológico de los tejidos blandos momificados; in Isidro A, Malgosa A (eds): Paleopatología, la enfermedad no escrita. Barcelona, Elsevier-Masson, 2003, pp 123-128.

27 Macadam RF, Sandison AT: The electron microscope in palaeopathology. Med Hist 1969; 13:81-85.

28 Lewin PK: Palaeo-electron microscopy of mummified tissue. Nature 1967,213:416-417.

29 Gerszten PC, Gerszten E, Allison MJ: Ultrastructure of a well-preserved lymphocyte from a mummified human. J Electron Microsc (Tokyo) 1997,46:443-445.

30 Hess MW, Klima G, Pfaller K, Kunzel KH, Gaber O: Histological investigation on the Tyrolean Ice Man. Am J Phys Anthropol 1998;106:521-532. 
31 Esteban J, Fernandez PL: Microscopía electrónica en tejidos momificados; in Isidro A, Malgosa A (eds): Paleopatología, la enfermedad no escrita. Barcelona, Elsevier-Masson, 2003, pp 129-137.

- 32 Nerlich AG, Parsche F, Kirsch T, Wiest I, von der Mark K: Immunohistochemical detection of interstitial collagens in bone and cartilage tissue remnants in an infant Peruvian mummy. Am J Phys Anthropol 1993;91:279285.

33 Hoyle CH, Thomas PK, Burnstock G, Appenzeller O: Immunohistochemical localisation of neuropeptides and nitric oxide synthase in sural nerves from Egyptian mummies. J Auton Nerv Syst 1997;67:105-108.

-34 Mekota AM, Vermehren M: Determination of optimal rehydration, fixation and staining methods for histological and immunohistochemical analysis of mummified soft tissues. Biotech Histochem 2005;80:7-13.

35 Fulcheri E: Immunohistochemistry: a new outlook in histopaleopathology. Boll Soc Ital Biol Sper 1995;71:105-110.

- 36 Campbell KL, Roberts JE, Watson LN, Stetefeld J, Sloan AM, Signore AV, Howatt JW, Tame JR, Rohland N, Shen TJ, Austin JJ, Hofreiter M, Ho C, Weber RE, Cooper A: Substitutions in woolly mammoth hemoglobin confer biochemical properties adaptive for cold tolerance. Nat Genet 2010;42:536-540.

- 37 Organ CL, Schweitzer MH, Zheng W, Freimark LM, Cantley LC, Asara JM: Molecular phylogenetics of mastodon and Tyrannosaurus rex. Science 2008;25:320:499.

- 38 Marota I, Rollo F: Molecular paleontology. Cell Mol Life Sci 2002;59:97-111.

- 39 Krause J, Fu Q, Good JM, Viola B, Shunkov MV, Derevianko AP, Pääbo S: The complete mitochondrial DNA genome of an unknown hominid from southern Siberia. Nature 2010;464:894-897.

-40 Green RE, Krause J, Briggs AW, Maricic T, Stenzel U, Kircher M, Patterson N, Li H, Zhai W, Fritz MH, Hansen NF, Durand EY, Malaspinas AS, Jensen JD, Marques-Bonet T, Alkan C, Prüfer K, Meyer M, Burbano HA, Good JM, Schultz R, Aximu-Petri A, Butthof A, Höber B, Höffner B, Siegemund M, Weihmann A, Nusbaum C, Lander ES, Russ C, Novod N, Affourtit J, Egholm M, Verna C, Rudan P, Brajkovic D, Kucan Z, Gusic I, Doronichev VB, Golovanova LV, Lalueza-Fox C, de la Rasilla M, Fortea J, Rosas A, Schmitz RW, Johnson PL, Eichler EE, Falush D, Birney E, Mullikin JC, Slatkin M, Nielsen R, Kelso J, Lachmann M, Reich D, Pääbo S: A draft sequence of the Neandertal genome. Science 2010;328:710-722.
41 Rollo F, Ubaldi M, Ermini L, Marota I: Otzi’s last meals: DNA analysis of the intestinal content of the Neolithic glacier mummy from the Alps. Proc Natl Acad Sci USA 2002; 99:12594-12599.

42 Konomi N, Lebwohl E, Zhang D: Comparison of DNA and RNA extraction methods for mummified tissues. Mol Cell Probes 2002;16:445-451.

43 Aufderheide AC: Soft tissue paleopathology: diseases of the viscera; in Aufderheide AC: The Scientific Study of Mummies. Cambridge, Cambridge University Press, 2003, pp 418-499.

44 Zimmerman MR: A possible histiocy toma in an Egyptian mummy. Arch Dermatol 1981; 117:364-365.

45 Fornaciari G, Castagna M, Naccarato AG, Tognetti A, Collecchi P, Bevilacqua G: Adenocarcinoma in the mummy of Ferrante I of Aragon, King of Naples. Paleopathol Newsl 1993;82:7-11.

46 Grevin G, Lagier R, Baud C: Metastatic carcinoma of presumed prostatic origin in cremated bones from the first century A.D. Virchows Arch 1997;431:211-214.

47 Nerlich AG, Rohrbach H, Bachmeier B, Zink A: Malignant tumors in two ancient populations: an approach to historical tumor epidemiology. Oncol Rep 2006;16:197-202.

-48 David AR, Zimmerman MR: Cancer: an old disease, a new disease or something in between? Nat Rev 2010;10:728-733.

49 Zink AR, Sola C, Reischl U, Grabner W, Rastogi N, Wolf H, Nerlich AG: Characterization of Mycobacterium tuberculosis complex DNAs from Egyptian mummies by spoligotyping. J Clin Microbiol 2003;41:359-367.

50 Ziskind B, Halioua B: Tuberculosis in ancient Egypt. Rev Mal Respir 2007;24:12771283 .

51 El-Najjar MY: Human treponematosis and tuberculosis: evidence from the New World. Am J Phys Anthropol 1979;51:599-618.

52 Castillo-Rojas G, Cerbón MA, López-Vidal Y: Presence of Helicobacter pylori in a Mexican Pre-Columbian mummy. BMC Microbiol 2008;8:119.

53 Nerlich AG, Schraut B, Dittrich S, Jelinek T, Zink AR: Plasmodium falciparum in ancient Egypt. Emerg Infect Dis 2008;14:1317-1319.

54 Fornaciari G, Marchetti A: Italian smallpox of the sixteenth century. Lancet 1986;ii:14691470 .
55 Aufderheide AC, Salo W, Madden M, Streitz J, Buikstra J, Guhl F, Arriaza B, Renier C, Wittmers LE Jr, Fornaciari G, Allison M: A 9,000-year record of Chagas' disease. Proc Natl Acad Sci USA 2004;101:2034-2039.

56 Allison MJ, Pezzia A, Hasegawa I, Gerszten E: A case of hookworm infestation in a Precolumbian American. Am J Phys Anthropol 1974;41:103-106.

57 Gerszten PC, Gerszten E, Allison MJ: Diseases of the spine in South American mummies. Neurosurgery 2001;48:208-213.

58 Ciranni R, Castagna M, Fornaciari G: Goiter in an eighteenth-century Sicilian mummy. Am J Phys Anthropol 1999;108:427432

59 Pabst M, Hofer F: Deposits of different origin in the lungs of the 5,300-year-old Tyrolean Iceman. Am J Phys Anthropol 1998;107:112.

60 Pääbo S: Molecular cloning of Ancient Egyptian mummy DNA. Nature 1985;314:644645.

61 Zimmerman MR, Aufderheide AC: The frozen family of Utqiagvik: the autopsy findings. Arctic Anthropol 1984;21:53-64.

62 Fisher C: Bog bodies of Denmark and northwestern Europe; in Cockburn A, Cockburn E, Reyman TA (eds): Mummies, Disease and Ancient Cultures. Cambridge, Cambridge University Press, 1998, pp 237-262.

63 Marchetti A, Pellegrini S, Bevilacqua G, Fornaciari G: K-ras mutation in the tumour of Ferrante I of Aragon, King of Naples. Lancet 1996;347:1272.

64 Fornaciari G, Giuffra V, Ferroglio E, Bianucci R: Malaria was 'the killer' of Francesco I de Medici (1531-1587). Am J Med 2010;123: 568-569.

- 65 Ordi J, Alonso PL, de Zulueta J, Esteban J, Velasco M, Mas E, Campo E, Fernández PL: The severe gout of Holy Roman Emperor Charles V. N Engl J Med 2006;355:516-520.

66 Hawaas Z: King Tut's family secrets. Natl Geographic 2010;218:34-59.

67 Capasso L: 5,300 years ago, the Ice Man used natural laxatives and antibiotics. Lancet 1998;352:1864.

68 Andrushko VA, Verano JW: Prehistoric trepanation in the Cuzco region of Peru: a view into an ancient Andean practice. Am J Phys Anthropol 2008;137:4-13.

69 David AR, Kershaw A, Heagerty A: Atherosclerosis and diet in ancient Egypt. Lancet 2010;375:718-719. 